\title{
ATTRACTION OF Bucephalogonia xanthophis (HEMIPTERA: CICADELLIDAE) TO VOLATILES OF ITS NATURAL HOST Vernonia condensata (ASTERACEAE)
}

\author{
José Maurício Simões Bento ${ }^{*}$; Alberto Arab $^{1}$; Giuliano Grici Zacarin ${ }^{1}$; André Gustavo Corrêa \\ Signoretti²; José Wilson Pereira da Silva² \\ ${ }^{1}$ USP/ESALQ - Depto. de Entomologia, Fitopatologia e Zoologia Agrícola - C.P. 09 - 13418-900 - Piracicaba, SP - \\ Brasil. \\ ${ }^{2}$ USP/ESALQ - Programa de Pós-Graduação em Entomologia. \\ *Corresponding author <jmsbento@esalq.usp.br>
}

\begin{abstract}
Plant volatiles are important cues for the orientation of herbivorous insects. It is possible that these compounds indicate whether the plant is suitable for feeding and larval development, or for mating aggregation. Vernonia condensata (Asteraceae) is known to attract species of leafhoppers, most of them important vectors of the citrus variegated chlorosis (CVC). In this study, we evaluated the role of volatiles of $V$. condensata on the orientation of Bucephalogonia xanthophis (Hemiptera: Cicadellidae). Four-arm olfactometer bioassays showed that only males were attracted to the volatiles of the host-plants Citrus sp. and V. condensata. Furthermore, fresh leaves of $V$. condensata induced a stronger response than volatiles from hexane-extracted leaves. This study opens the possibility to utilize $V$. condensata volatiles for pest management programs of B. xanthopis.
\end{abstract}

Key words: plant-herbivore interaction, leafhopper, trichomes

\section{ATRATIVIDADE DE Bucephalogonia xanthophis (CICADELLIDAE) POR VOLÁTEIS DE SEU HOSPEDEIRO NATURAL Vernonia condensata (ASTERACEAE)}

\begin{abstract}
RESUMO: Os voláteis de plantas são sinais importantes para a orientação de insetos herbívoros. É possível que esses compostos indiquem que a planta é apropriada para alimentação e desenvolvimento larval, ou para agrupamento reprodutivo. Vernonia condensata (Asteraceae) atrai espécies de cigarrinhas, muitas delas vetores da clorose variegada dos citros (CVC). Neste trabalho, foi avaliado o papel dos voláteis de $V$. condensata na orientação de Bucephalogonia xanthophis (Hemiptera: Cicadellidae). Bioensaios em olfatômetro de quatro braços mostraram que somente os machos foram atraídos pelos voláteis das plantas hospedeiras Citrus sp. e V. condensata, sendo que os voláteis das folhas frescas de $V$. condensata induziram uma maior resposta quando comparada aos extratos hexânicos da planta. A possibilidade de usar os voláteis de $V$. condensata abre novas perspectivas para programas e alternativas para o manejo de pragas.

Palavras-chave: interação planta-herbívoro, cigarrinha, tricomas
\end{abstract}

\section{INTRODUCTION}

In response to herbivore damage, plants synthesize and release complex blends of volatile compounds that serve as indirect defenses mediating the attraction of predators and/or parasitoids of the herbivores responsible for the damage (Turlings \& Wackers, 2004; De Boer et al., 2004; Kessler \& Baldwin, 2001; De Moraes et al., 1998; Vet \& Dicke, 1992). Herbivory is not the only factor inducing the release of plant volatiles, even deposition of eggs by herbivorous arthropods has also been shown to induce volatile attractants (Hilker \& Meiners, 2006; Colazza et al., 2004). However, plant volatiles represent a complex message that is interpreted according to the biological context of other insects and these compounds may also attract other herbivores and thereby incur ecological costs for plants (Bengtsson et al., 2006; Hori et al., 2006; Srinivasan et al., 2006; Heil, 2004; Kessler \& Baldwin, 2002; Visser, 1986).

The leafhopper Bucephalogonia xanthophis (Berg) (Hemiptera: Cicadellidae) is the vector of the bacterium Xylella fastidiosa, the causal agent of citrus variegated chlorosis (CVC), a disease that in southeastern Brazil affects $40 \%$ of the citrus crops (Milanez et al., 2001). Although the genome of $X$. fastidiosa has been sequenced, the mechanisms that control the process of infection and the development of the disease 
remain unknown (Simpson et al., 2000), and several aspects of the interaction with the host plants need to be clarified in order to improve management techniques for this important disease.

Based on the knowledge on the tritrophic interactions increases, one of the major challenges in Brazil is how to exploit plant volatile information to develop novel strategies for pest control. The possibility of using plant volatiles for the manipulation of parasitoids appears to be a powerful tool for the control of regional pest crops, as demonstrated by the results obtained in experiments using the parasitoids $T$. podisi in soybean (Moraes et al., 2005) and Tamarixia radiata (Waterston) (Hymenoptera: Eulophidae) in citrus (Arab et al., unpublished).

Vernonia condensata Becker (Asteraceae) is a natural host of various Cicadellidae vectors of the CVC disease (Milanez et al., 2001). Insect vectors are strongly attracted to this plant, for instance, the leafhopper B. xanthophis is found infecting both citrus and $V$. condensata plants in greenhouses and orchards in the São Paulo State, Brazil. The objective of this preliminary study was to evaluate the role of the volatiles released by $V$. condensata on the response of B. xanthophis, with the aim of understanding the biology of this citrus pest in order to improve further control and integrated management programs for this insect.

\section{MATERIAL AND METHODS}

Insects and Plants - Adults of the leafhopper $B$. xanthophis were collected from Duranta repens (Verbenaceae) plants in Piracicaba, State of São Paulo $\left(22^{\circ} 42^{\prime} \mathrm{S} ; 47^{\circ} 37^{\prime} \mathrm{W}\right)$, Brazil, transferred to the laboratory, and caged with the plant $D$. repens, to avoid conditioning to volatiles from plants used in the subsequent experiments (Milanez et al., 2003). Stem fragments of one individual of $V$. condensata were collected and rooted in $300 \mathrm{~mL}$ plastic tubes and used after the development of the first ten leaves. Insects and plants were kept inside a greenhouse at $25 \pm 5^{\circ} \mathrm{C}, 70 \pm 10 \%$ $\mathrm{RH}$ and natural photoperiod. Fresh leaves from Citrus sp. (Rutaceae) and the non-host plant Paspalum notatum (Poaceae) were also collected one-hour prior to the beginning of the bioassays.

Leaf Morphology - Scanning Electron Microscopy (SEM) was carried out on leaves of $V$. condensata fixed in Karnovsky (Karnovsky, 1965) and performed in whole mounts. These samples were prepared using critical point drying and gold sputtering of fixed leaves and examined with a Zeiss Mev DSM940A scanning electron microscope.
Four-arm Olfactometer Bioassays - Preference of adults of $B$. xanthophis by host and non-host plant volatile compounds was evaluated in a $30 \times 30 \mathrm{~cm}$ four-arm olfactometer, as described by Vet et al. (1983). Plants tested in this bioassay included excised healthy leaves of the host plants V. condensata and Citrus sp. (Rutaceae), and leaves of the non-host plant $P$. notatum (Poaceae). A wetted cotton was placed at the distal end of the excised leaves to avoid dessecation during the experiment. Bioassays were conducted using males and females of B. xanthophis. Each trial consisted of a combination of three odor sources offered to the insects (leaves of V. condensata, Citrus sp., and $P$. notatum), while one chamber was kept empty (humidified air) (Vet et al., 1983). Plant material was randomly assigned to the arms and replaced after testing five insects to avoid induction of other compounds. Insects were introduced individually at the center of the olfactometer and observed for $10 \mathrm{~min}$. Preference for one of the samples was considered positive if the insect moved towards one field of the olfactometer. The insect response to volatiles was measured using the time spent walking in each odor field. After each trial, the olfactometer was disassembled and its central arena, tubes, and connections were washed with neutral dishwashing soap (5\%) and 90\% ethanol (Vet et al., 1983). All the bioassays were conducted with fluorescent light inside a controlled environmental room at $25 \pm 3^{\circ} \mathrm{C}$ and $70 \pm 10 \% \mathrm{RH}$. Twenty replicates were conducted per sex in this experiment.

Volatile Extraction of V. condensata Leaves - Leaf volatiles of $V$. condensata were collected using a noninvasive extraction method (Duke et al., 2000). Extraction was performed using $20 \mathrm{~g}$ of fresh leaves washed with $5 \mathrm{~mL}$ of hexane for 30 seconds. The hexane-extract was tested in the four-arm olfactometer, as described above, and compared with the activity of fresh leaves. Hexane was used as solvent control. Twenty replicates were conducted in this experiment.

Statistics - Differences between the means of the time spent by the insects in each field of the olfactometer were evaluated by an analysis of variance (One-Way ANOVA) $(p<0.05)$. Multiple comparisons were conducted with a Tukey test $(p<0.05)$ (Sheskin, 2000).

\section{RESULTS AND DISCUSSION}

Some herbivorous arthropods can detect their hosts using volatile compounds released by healthy plants, which can also stimulate oviposition and courtship behaviors in these organisms (Rojas et al., 2003). Only males of the leafhopper B. xanthopis responded 
to volatiles released for their host plants (Table 1). The time spent by males in the olfactometer also showed differences among the samples tested $(\mathrm{F}=2.96$; $\mathrm{df}=3 ; p=0.037$; ANOVA). Individuals spent more time for Citrus sp. than for $P$. notatum and humidified air ( $p=0.049$ and $p=0.004$, respectively; Tukey test). Moreover, no differences between the host plants were detected ( $p=0.162$; Tukey test). Differences between the behavioral responses of the insects exposed to plant volatiles and their correlation with sex and physiological state have been reported for many insectplant interactions (Dickens, 2000). The internal state of an animal, such as reproductive stage or sex, also influences its foraging behavior (see Vet \& Dicke, 1992, for review).

Variation in the sensibility of the antennal receptors and specificity between males and females may explain sex biased plant-volatile attraction in some insects (Fraser et al., 2003). Plant volatiles can also influence sex pheromone communication by enhancing both pheromone production and response (Landolt \& Phillips, 1997). The effect of the sex pheromone of Cydia pomonella L. (Lepidoptera: Tortricidae) on males is greatly enhanced by volatiles released by the host plants, thus increasing communication distances by amplifying weak pheromone signals (Yang et al., 2004). Moreover, the synergism between host plant volatiles and sex pheromones also plays an important role in reproductive isolation (Witzgall et al., 1991). It is possible that volatile compounds of $V$. condensata indicate that the plant is suitable for mating aggregation (Fraser et al., 2003; Meiners \& Hilker, 2000); however, further studies are necessary to determine the role of other semiochemicals, such as sex pheromones, on the response of $B$. xanthopis males to host plants.
To determine if volatile compounds can be isolated from leaves of $V$. condensata using a non-invasive extraction protocol, males were tested by comparing the preference for volatiles of hexane leaf extracts against fresh leaves. Volatiles of the host plant elicited orientation on the insects $(\mathrm{F}=12.69$; $\mathrm{df}=1$; $p=0.006$; ANOVA). There were no differences on the preference of the males of $B$. xanthopis between hexane-extracted-volatiles and fresh leaves treatments ( $p=0.107$; Tukey test). However, fresh leaves of $V$. condensata appear to elicit a stronger orientation on the males of B. xanthopis over the solvent control and humidified air ( $p=0.005$ and $p=0.0003$, respectively; Tukey test), than hexane-extracted-volatiles ( $p=0.210$ and $p=0.031$, respectively; Tukey test) (Table 2). Although both fresh leaves and hexane-extracted-volatiles elicited orientation behavior on the insects, the variation seen for the activity of both treatments indicate that not all the volatile compounds were recovered using the non-invasive method with hexane. Thus, a direct extraction of the headspace volatiles (Fraser et al., 2003) will be more useful for behavioral bioassays with $V$. condensata.

Other herbivorous insects are attracted to host plant volatiles. The Colorado potato beetle Leptinotarsa decemlineata Say (Coleoptera: Chrysomelidae) is attracted to damaged Solanum tuberosum L. (Solanaceae) plants (Dickens, 2002). Volatile compounds released by glandular trichomes of Cordia curassavica Jaq. R.\&S. (Boraginaceae) are strong attractants for the weevil Cratosomus flavofasciatus Guerin (Coleoptera: Curculionidae), which is also an important pest of some Brazilian fruit cultivars, including citrus species (Arab \& Bento, 2006). Consequently, for herbivores, plant volatiles represent a complex message that is interpreted according to their biological context.

Table 1 - Mean spent time ( \pm SE) of adults of Bucephalogonia xanthopis to volatiles released by host and non-host plants $(\mathrm{N}=20)$.

\begin{tabular}{lcrrrrr}
\hline \multirow{2}{*}{ Response } & \multirow{2}{*}{ Sex } & \multicolumn{4}{c}{ Odour field } \\
\cline { 3 - 7 } & & Vernonia condensata & Citrus sp. & Paspalum notatum & \multicolumn{1}{c}{ Air } \\
\hline \multirow{2}{*}{ Time/field $(\mathrm{seg})^{*}$} & $\mathrm{M}$ & $158.10 \pm 45.77 \mathrm{ab}$ & $238.75 \pm 46.51 \mathrm{~b}$ & $132.40 \pm 39.29 \mathrm{a}$ & $70.75 \pm 27.21 \mathrm{a}$ \\
& $\mathrm{F}$ & $172.80 \pm 49.89 \mathrm{a}$ & $147.7 \pm 48.00 \mathrm{a}$ & $145.70 \pm 45.79 \mathrm{a}$ & $133.80 \pm 45.79 \mathrm{a}$ \\
\hline
\end{tabular}

*One-way ANOVA $(p<0.05)$. Different letters in the same row indicate differences of time spent between samples (Tukey test). (M $=$ Male; $\mathrm{F}=$ Female).

Table 2 - Mean spent time ( \pm SE) of males of Bucephalogonia xanthopis to fresh leaves and hexane-extracted-volatiles of Vernonia condensata $(\mathrm{N}=20)$.

\begin{tabular}{lcccc}
\hline \multirow{2}{*}{ Response } & \multicolumn{4}{c}{ Odour field } \\
\cline { 2 - 5 } & Hexane & Fresh Leaves & Air & Hexane Extract \\
\hline Time/field $(\mathrm{seg}) *$ & $100.0 \pm 40.46$ bc & $279.05 \pm 55.83$ a & $42.60 \pm 18.39 \mathrm{c}$ & $178.30 \pm 50.62 \mathrm{ab}$ \\
\hline *One-way ANOVA $(p<0.05)$. Different letters in the same row indicate differences of time spent between samples (Tukey test).
\end{tabular}



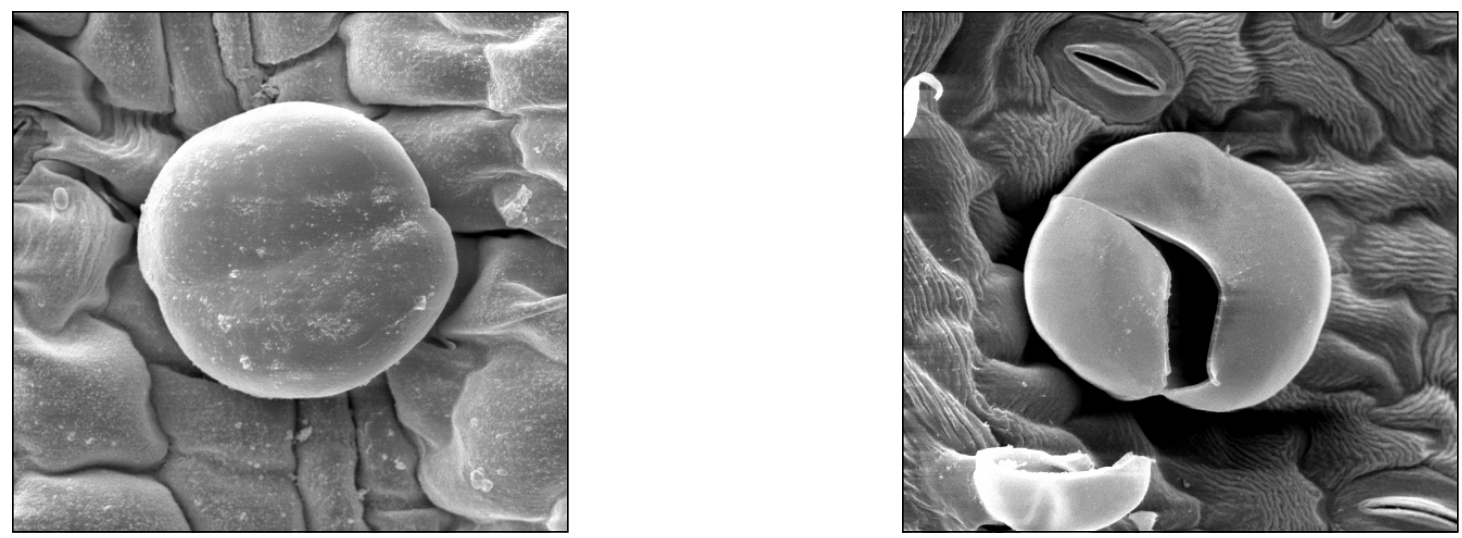

Figure 1 - Capitate-sessile trichomes of Vernonia condensata. General view of a trichome filled with secretion (left), and after it content was released (right).

SEM of $V$. condensata leaves showed a high number of capitate-sessile glandular trichomes (Figure 1). The mean number of these structures was 132 trichomes $\mathrm{cm}^{-2}$ and 1299 trichomes $\mathrm{cm}^{-2}$ on the adaxial and abaxial surfaces, respectively. This result indicates that the higher number of these structures occurs together with stomata. The diameter of the glandular trichomes was $49.1 \pm 4.4 \mu \mathrm{m}$. The presence of glandular trichomes in plants is an important constitutive defense against herbivorous arthropods (Harborne, 1991); however, the presence of these structures could be related to the release of plant volatile compounds that are attractive to the leafhoppers. This possibility should be further investigated.

Field evaluations of plant volatiles suggest that some synthetic blends are attractive to certain insects (James, 2005; James, 2003), which opens new perspectives for the introduction of intercrops or trap crops technologies and traps with synthetic blends of volatiles (Khan et al., 2006; Gohole et al., 2003; James, 2003; Khan et al., 1997). This study involves a mechanistic approach, focusing on the response of the leafhopper B. xanthopis to a host plant and opens the possibility to identify and synthesize $V$. condensata volatiles for pest management programs of this insect.

\section{ACKNOWLEDGEMENTS}

To Johana Rincones for reviewing the grammar and syntax of the English text. This work was supported by FAPESP (Fundação de Amparo à Pesquisa no Estado de São Paulo), grants number 04/ 12365-4 and 01/06587-6.

\section{REFERENCES}

ARAB, A.; BENTO, J.M.S. Plant volatiles:new perspectives for research in Brazil. Neotropical Entomology, v.35, p.151-158, 2006.
BENGTSSON, M.; JAASTAD, G.; KNUDSEN, G.; KOBRO, S.; BACKMAN, A.C.; PETTERSSON, E.; WITZGALL, P. Plant volatiles mediate attraction to host and non-host plant in apple fruit moth, Argyresthia conjugella. Entomologia Experimentalis et Applicata, v.118, p.77-85, 2006.

COLAZZA, S.; FUCARINO, A.; PERI, E.; SALERNO, G.; CONTI, E.; BIN, F. Insect oviposition induces volatile emission in herbaceous plants that attracts egg parasitoids. Journal of Experimental Biology, v.207, p.47-53, 2004.

DE BOER, J.G.; POSTHUMUS, M.A.; DICKE, M. Identification of volatiles that are used in discrimination between plants infested with prey or nonprey herbivores by a predatory mite. Journal of Chemical Ecology, v.30, p.2215-2230, 2004.

DE MORAES, C.M.; LEWIS, W.J.; PARE, P.W.; ALBORN, H.T.; TUMLINSON, J.H. Herbivore-infested plants selectively attract parasitoids. Nature, v.11, p.570-573, 1998.

DICKENS, J.C. Sexual maturation and temporal variation of neural responses in adult Colorado potato beetles to volatiles emitted by potato plants. Journal of Chemical Ecology, v.26, p.1265$1279,2000$.

DICKENS, J.C. Behavioural responses of larvae of Colorado potato beetle, Leptinotarsa decemlineata (Coleoptera: Chrysomelidae), to host plant volatile blends attractive to adults. Agriculturaland-Forest-Entomology, v.4, p.309-314, 2002.

FRASER, A.M.; MECHABER, W.L.; HILDEBRAND, J.G. Electroantennographic and behavioral responses of the sphinx moth Manduca sexta to host plant headspace volatiles. Journal of Chemical Ecology, v.29, p.1813-1833, 2003.

GOHOLE, L.S.; OVERHOLT, W.A.; KHAN, Z.R.; PICKETT, J.A.; VET, L.E.M. Effects of molasses grass, Melinis minutiflora volatiles on the foraging behavior of the cereal stemborer parasitoid, Cotesia sesamiae. Journal of Chemical Ecology, v.29, p.731-745, 2003.

HEIL, M. Direct defense or ecological costs: responses of herbivorous beetles to volatiles released by wild lima bean (Phaseolus lunatus). Journal of Chemical Ecology, v.30, p.1289-1295, 2004.

HILKER, M.; MEINERS, T. Early herbivore alert: Insect eggs induce plant defense. Journal of Chemical Ecology, v.32, p.13791397, 2006.

HORI, M.; OHUCHI, K.; MATSUDA, K. Role of host plant volatile in the host-finding behavior of the strawberry leaf beetle, Galerucella vittaticollis Baly (Coleoptera: Chrysomelidae). Applied Entomology Zoology, v.41, p.357363, 2006.

JAMES, D.G. Field evaluation of herbivore-induced plant volatiles as attractants for beneficial insects: Methyl salicylate and the green lacewing, Chrysopa nigricornis. Journal of Chemical Ecology, v.29, p.1601-1609, 2003. 
JAMES, D.G. Further field evaluation of synthetic herbivore-induced plant volatiles as attractants for beneficial insects. Journal of Chemical Ecology, v.31, p.481-495, 2005.

KARNOVSKY, M.J. A formaldehyde-glutaraldehyde fixative of high osmolarity for use in electron microscopy. Journal of Cell Biology, v.27, p.137-138, 1965.

KESSLER, A.; BALDWIN, I.T. Plant-mediated tritrophic interactions and biological pest control. AgBiotechNet, v.4, p.1-6, 2002.

KESSLER, A.; BALDWIN, I.T. Defensive function of herbivoreinduced plant volatile emissions in nature. Science, v.291, p.2141-2144, 2001 .

KHAN, Z.R.; AMPONGNYARKO, K.; CHILISWA, P.; HASSANALI, A.; KIMANI, S.; LWANDE, W.; OVERHOLT, W.A.; PICKETT, J.A.; SMART, L.E.; WADHAMS, L.J.; WOODCOCK, C.M. Intercropping increases parasitism of pests. Nature, v.388, p.631-632, 1997.

KHAN, Z.R.; PICKETT, J.A.; WADHAMS, L.J.; HASSANALI, A.; MIDEGA, C.A.O. Combined control of Striga hermonthica and stemborers by maize-Desmodium spp. intercrops. Crop Protection, v.25, p.989-995, 2006.

LANDOLT, P.T.; PHILLIPS, T.W. Host plant influences on sex pheromone behavior of phytophagous insects. Annual Review of Entomology, v.42, p.371-391, 1997.

MEINERS, T.; HILKER, M. Induction of plant synomones by oviposition of a phytophagous insect. Journal of Chemical Ecology, v.26, p.221-232, 2000.

ROJAS, J.C.; VIRGEN, A.; CRUZ-LOPEZ, L. Chemical and tactile cues influencing oviposition of a generalist moth, Spodoptera frugiperda (Lepidoptera: Noctuidae). Environmental Entomology, v.32, p.1386-1392, 2003.

SHESKIN, D. Handbook of parametric and nonparametric statistical procedures. 2 ed. Boca Raton: CRC Press, 2000. 982 p.
SRINIVASAN, R.; UTHARNASAMY, S.; TALEKAR, N.S. Characterization of oviposition attractants of Helicoverpa armigera in two solanaceous plants, Solanum viarum and Lycopersicon esculentum. Current Science, v.90, p.846-850, 2006.

TURLINGS, T.C.J.; WACKERS, F. Recruitment of predators and parasitoids by herbivore-injured plants. In: CARDE, R.T.; MILLAR, J.G. (Ed.) Advances in insect chemical ecology. Cambridge: Cambridge University Press, 2004. p.21-75.

VET, L.E.M.; DICKE, M. Ecology of infochemical use by natural enemies in a tritrophic context. Annual Review Entomology. v.37, p.141-172, 1992.

VET, L.E.M.; VANLENTEREN, J.C.; HEYMANS, M.; MEELIS, E. An air-flow olfactometer for measuring olfactory responses of hymenopterous parasitoids and other small insects. Physiological Entomology, v.8, p.97-106, 1983.

VISSER, J.H. Host odour perception in phytophagous insects. Annual Review Entomology, v.31, p.121-144, 1986.

WITZGALL, P.; BENGTSSON, M.; CHAMBON, J.-P.; PRIESNER, E.; WILDBOLZ, T.; ARN, H. Sex pheromones of Spilonota ocellana and Spilonota laricana. EntomologiaExperimentalis-et-Applicata, v.60, p.219-223, 1991.

YANG, Z.; BENGTSSON, M.; WITZGALL, P.; YANG, Z.H. Host plant volatiles synergize response to sex pheromone in codling moth, Cydia pomonella. Journal of Chemical Ecology. v.30, p.3-629, 2004.

Received February 06, 2007

Accepted March 13, 2008 